\title{
Pengembangan Bahan Ajar Simak Berorientas Kearifan Lokal untuk Meningkatkan Kemampuan Literasi Mahasiswa pada Mata Kuliah Menyimak
}

\author{
Tri Pujiatna ${ }^{1)}$, Elin Rosmaya ${ }^{2)}$, Nuning Wahyuningsih ${ }^{3)}$
}

Prodi Pendidikan Bahasa dan Sastra Indonesia Univeristas Swadaya Gunung Jati ${ }^{12) 3}$ ) tpujiatna@gmail.com ${ }^{1)}$, elin.unswagati@gmail.com ${ }^{2)}$, nuningwahyuningsih2@gmail.com ${ }^{3)}$

\begin{abstract}
Abstrak. Bahan/materi ajar perlu dikembangkan serta diorganisasikan secara mantap dan matang agar pembelajaran tidak melenceng dari tujuan yang harus dicapai. Penelitian ini menghasilkan bahan ajar berupa Lembar Kerja Mahasiswa bermedia simak/audio berkearifal lokal yang akan diimplementasikan pada mata kuliah menyimak. Dalam mata kuliah ini, mahasiswa dilatih kemampuan menyimaknya dengan cara menyuguhkan berbagai macam informasi. Hal ini dilakukan agar mahasiswa terbiasa menyimak informasi dan dapat menangkap informasi dengan baik. Adapun tujuan penelitian ini adalah merancang bahan ajar, mendeskripsikan kemampuan literasi mahasiswa serta mengetahui keefektifan bahan ajar simak berorientasi kearifan lokal dalam mata kuliah menyimak pada Program Studi Pendidikan Bahasa Indonesia Universitas Swadaya Gunung Jati. Penelitian ini dilakukan dengan alasan ditemukannya data bahwa kemampuan literasi (daya simak) mahasiswa masih rendah. Pemilihan tema kearifan lokal pada penelitian ini didasarkan atas pertimbangan belum tergalinya potensi daerah secara maksimal sebagai bahan literasi seperti kebiasaan-kebiaasan, adat, budaya serta pariwisata di wilayah Ciayumajakuning (Cirebon, Indramayu, Majalengka, dan Kuningan). Pemilihan kearifan lokal ini tidak lepas dari pertimbangan mahasiswa Universitas Swadaya Gunung Jati banyak berasal dari wilayah tersebut. Pengembangan bahan ajar berorientasi kearifan lokal ini menggunakan model ADDIE (Analysis-Design-Develop-ImplementEvaluate). Model pengembangan bahan ajar ini meliputi analisis, perancangan, pengembangan (uji coba), Implementasi, dan Evaluasi terhadap bahan ajar simak.
\end{abstract}

Kata Kunci : bahan ajar simak, literasi, menyimak, kearifan lokal.

\section{Pendahuluan}

Kegiatan pembelajaran di dalam dunia pendidikan merupakan hal inti yang harus dilakukan. Salah satu alat untuk mendukung kegiatan pembelajaran tersebut adalah kurikulum. Undang-Undang Sistem Pendidikan Nasional Tahun 2003 Bab I pasal 1 menyebutkan bahwa kurikulum adalah seperangkat rencana dan peraturan mengenai isi dan bahan pelajaran serta cara yang digunakan sebagai pedoman penyelenggara kegiatan belajar mengajar. Berdasarkan hal ini, dapat diketahui bahwa kurikulum berisi rencana dan peraturan mengenai isi dan bahan pelajaran, sementara pengembangannya harus dilakukan oleh pendidik. Hal ini sesuai dengan PP Nomor 19 Tahun 2005 Pasal 20 yang menyatakan bahwa pendidik diharapkan dapat mengembangkan materi pembelajaran. Berdasarkan UU Sisdiknas tahun 2003 dan PP No. 19 Tahun 2005 Pasal 20 membuktikan bahwa di dalam proses pembelajaran pendidik diberikan kebebasan dalam mengembangkan kurikulum. Salah satu yang perlu dikembangkan adalah materi ajar atau bahan pelajaran. Wismanto (2014) menjelaskan bahwa bahan ajar atau materi pembelajaran (instructional materials) secara garis besar terdiri atas pengetahuan, keterampilan, dan sikap yang harus dipelajari siswa dalam rangka mencapai standar kompetensi yang telah ditentukan.

Tri Pujiatna, Elin Rosmaya, Nuning Wahyuningsih| Pengembangan Bahan Ajar Simak Berorientas Kearifan Lokal Untuk 
Bahan ajar adalah segala bentuk bahan yang digunakan untuk membantu guru atau instruktur dalam melaksanakan kegiatan belajar mengajar di kelas. Penggunaan bahan ajar diharapkan dapat memberikan dampak yang positif bagi peserta didik terutama pada ranah pengetahuan, keterampilan, dan sikap. Selain itu, pengembangan bahan ajar yang dikembangkan dapat dijadikan sebagai bantuan bagi pendidik dalam proses pembelajaran. Hamdani (2011) adalah segala bentuk bahan atau materi yang disusun secara sistematis yang digunakan untuk membantu guru atau instruktur dalam melaksanakan kegiatan belajar mengajar sehingga tercipta lingkungan atau suasana yang memungkinkan siswa untuk belajar.

Bahan ajar tidak sekadar berupa kumpulan materi pembelajaran. Bahan ajar merupakan seperangkat sarana atau alat pembelajaran yang berisikan materi pembelajaran, metode, batasan-batasan, dan cara mengevaluasi yang didesain secara sitematis dan menarik dalam rangka mencapai tujuan yang diharapkan, yaitu mencapai kompetensi atau subkompetensi dengan segala kompleksitasnya (Widodo \& Jasmadi, 2008). Hal membuktikan bahwa dalam mengembangkan bahan ajar membutuhkan perencanaan yang baik sehingga dapat memberikan manfaat bagi penggunanya.

Prastowo (2011) Fungsi bahan ajar dapat dibedakan menjadi tiga macam, yaitu fungsi dalam pembelajaran klasikal, pembelajaran individual, dan pembelajaran kelompok. Berikut fungsi bahan ajar; a) Pembelajaran klasikal antara lain, sebagai satu-satunya sumber informasi serta pengawas dan pengendali proses pembelajaran dan sebagai bahan pendukung proses pembelajaran yang diselenggarakan; b) pembelajaran individual antara lain, sebagai media utama dala proses pembelajaran, sebagai alat yang digunakan untuk menyusun dan mengawasi proses peserta didik dalam memperoleh informasi, dan sebagai penunjang media pembelajaran individual lainnya; c) pembelajaran kelompok antara lain, sebagai bahan yang terintegrasi dengan proses belajar kelompok dengan cara memberikan informasi tentang latar belakang materi, dan sebagai bahan pendukung belajar utama yaitu dapat meningkatkan motivasi belajar siswa.

Bahan ajar dapat berupa bahan tertulis maupun tidak tertulis. Adapun bentuk bahan ajar dibedakan menjadi empat macam, yaitu; 1) Bahan ajar cetak (printed); 2) Bahan ajar dengar (audio) atau program audio; 3) Bahan ajar pandang dengar (audio visual); dan 4) Bahan ajar interaktif (interactive teaching materials) (Prastowo, 2011). Berdasarkan bentukbentuk bahan ajar tersebut pendidik diharapkan dapat mengembangkan bahan ajar yang sesuai dengan karakteristik metari ajar, peserta didik, dan pertimbangan lainnya. Pemilihan jenis bahan ajar yang tepat akan menciptakan situasi pembelajaran yang terstandar, sesuai dengan tujuan serta capaian pembelajaran.

Penelitian ini akan mengembangkan bahan ajar cetak berupa Lembar Kerja (LK) yang dikombinasikan dengan bahan ajar audio untuk diterapkan pada mata kuliah Menyimak sebagai upaya untuk meningkatkan keterampilan menyimak mahasiswa FKIP Pendidikan Bahasa Indonesia Universitas Swadaya Gunung Jati. Pada mata kuliah ini akan membahas berbagai teori, macam, proses, teknik, serta hambatan menyimak. Dalam proses pembelajaran mata kuliah Menyimak, mahasiswa akan sering dilatih kemampuan menyimaknya dengan cara menyuguhkan berbagai macam informasi. Hal ini dilakukan agar mahasiswa terbiasa menyimak informasi dan dapat menangkap informasi dengan baik. 
Penelitian ini dilakukan didasari atas temuan data bahwa kemampuan literasi (daya simak) mahasiswa masih rendah. Hal ini dapat dilihat dari nilai kemampuan mendengarkan mahasiswa di bawah rata-rata. Selain itu, belum tergalinya potensi daerah secara maksimal sebagai bahan literasi seperti kebiasaan-kebiaasan, adat, budaya serta pariwisata di Ciayumajakuning sebagai bahan simak. Materi simak yang diperdengarkan kepada mahasiswa adalah informasi yang memuat tema kearifan lokal.

Tema kearifan lokal yang akan diangkat adalah kearifan lokal yang berada di wilayah Ciayumajakuning (Cirebon, Indramayu, Majalengka, dan Kuningan). Maridi (2015) menjelaskan bahwa kearifan lokal menjadi salah satu hal yang harus diperhatikan dalam kegiatan perlindungan dan pengelolaan lingkungan hidup. Dengan kata lain, bahwa kearifan lokal merupakan sebuah pengetahuan yang eksplisit dan muncul dari periode panjang yang ber-evolusi bersama-sama masyarakat dan lingkungannya dalam sistem lokal untuk menghadapi pengaruh budaya asing. Selanjutnya, Basyari (2014) menjelaskan bahwa nilai budaya lokal harus dipandang sebagai warisan sosial yang memiliki nilai berharga bagi kebanggaan dan kebesaran martabat bangsa. Melalui upaya ini, mahasiswa mampu mengenal nilai-nilai budaya daerahnya sehingga tetap lestari dan menjadi suatu kebanggan pada dirinya sebagai warga negara yang memiliki keanekaragaman budaya. Selain itu, kearifan lokal mempunyai tujuan pembentukan manusia yang mempunyai pemahaman, sikap, dan perilaku yang berkarakter dan memiliki nilai-nilai luhur (Febriani, 2012)

Tujuan penelitian ini ingin mengembangkan bahan ajar simak berorientasi pada kearifan lokal berupa lembar kerja (LK). Selain itu, penelitian ini juga diharapakam dapat meningkatkan kemampuan literasi mahasiswa. Literasi dimaknai sebagai bentuk sarana untuk mengenal, memahami, dan menerapkan pengetahuan yang didapat, baik melalui pendidikan di sekolah, keluarga maupun masyarakat sekitar. Di dalam dunia pendidikan, buku-buku pelajaran ataupun buku bacaan merupakan sarana untuk memperoleh pengetahuan. Hal ini menunjukkan bahwa budaya membaca dan menulis merupakan penting. Seiring dengan perkembangan zaman, literasi tidak sekadar mencakup keterampilan membaca dan menulis saja. Namun, literasi mencakup keterampilan berpikir dalam menggunakan sumber-sumber pengetahuan dalam bentuk cetak, visual, auditori, dan digital (Sutrianto, dkk., 2016).

Adapun langkah-langkah yang dilakukan untuk membuat Lembar Kerja (LK) dalam penelitian ini, yaitu 1) Melakukan Analisis Kurikulum; 2) Menyusun Peta Kebutuhan LKS; 3) Menentukan Judul-Judul LKS; dan 4) Penulisan LKS. Selanjutnya, pengembangan bahan ajar simak yang akan dikembangkan meliputi empat tataran, 1) tataran identifikasi; 2) tataran identifikasi dan seleksi tanpa retensi; 3) Tataran identifiksai dengan seleksi terpimpin dan retensi jangka pendek; dan 4) tataran identifikasi dengan seleksi retensi jangka panjang.

\section{Metode}

Pengembangan bahan ajar simak ini dilakukan terhadap bahan ajar simak yang dilengkapi dengan Lembar Kerja (LK). Bahan ajar yang dikembangkan merujuk pada model pengembangan bahan ajar model ADDIE (Analysis-Design-Develop-Implement-Evaluate). Model pengembangan bahan ajar ini meliputi analisis, perancangan, pengembangan, Implementasi, dan Evaluasi terhadap bahan ajar simak. 
Penelitian ini bertujuan untuk mengetahui kemampuan literasi mahasiswa serta keefektifan bahan ajar simak yang akan diterapkan pada mahasiswa tingkat 1 semester 1 yang mengontrak mata kuliah Menyimak. Ada pun tahapan-tahapan yang dilakukan

1. Mendokumentasikan teks berorientasi kearifan lokal Ciayumajakuning. Kemudian dilanjutkan menganalisis teks tersebut berdasarkan kebutuhan.

2. Mendesain rancangan bahan berupa lembar kerja serta melakukan rekaman simak.

3. Mengembangkan bahan ajar berupa lembar kerja berdasarkan rancangan desain.

4. Setelah, bahan ajar dikembangkan, kemudian diujicoba terbatas.

5. Setelah diujicoba, bahan ajar divalidasi oleh para ahli untuk diuji validitasnya. Hasil uji coba dan validasi akan digunakan sebagai bahan masukan untuk direvisi bahan ajar yang akan dikembangkan.

6. Setelah direvisi berdasarkan hasil diujicoba terbatas dan diuji validasi, bahan ajar siap untuk diterapkan dalam proses pembelajaran di kelas pada mata kuliah Menyimak.

\section{Hasil dan Pembahasan}

Pengembangannya bahan ajar didasarkan pada tahapan model ADDIE (Analysis, Design, Develop, Implement, Evaluate). Berikut hasil pengembangan bahan ajar berorientasi pada berkearifan lokal Ciayumajakuning untuk meningkatkan kemampuan literasi mahasiswa pada mata kuliah Menyimak, sebagai berikut:

1. Analysis : Pada tahap ini peneliti mengawali dengan menganalisis silabus dan RKPS mata kuliah Menyimak untuk membuat kebutuhan di dalam pelaksanaan pembelajaran serta menganalisis teks kearifan lokal Ciayumajakuning sebagai bahan simak untuk meningkatkan kemampuan literasi informasi mahasiswa. Hal ini merujuk pada pendapat Nurchaili (2016) menjelaskan bahwa literasi informasi merupakan kemampuan untuk menyadari kebutuhan informasi dan saat informasi diperlukan, mengidentifikasi dan menemukan lokasi informasi yang diperlukan, mengevaluasi informasi secara kritis, mengorganisasikan dan mengintegrasikan informasi ke dalam pengetahuan yang sudah ada, memanfaatkan serta mengkomunikasikannya secara efektif, legal, dan etis. Pemilihan kearifan lokal juga disesuaikan dengan bobot informasi yang dibutuhkan mahasiswa. Dengan demikian, wawasan pengetahuan mahasiwa mengenai kearifan lokal di daerahnya menjadi bertambah. teks kearifan lokal yang telah dikumpulkan untuk bahan ajar simak, dipilih kembali dengan cara menganalisis karakteristik bahasa, informasi dan jumlah materi. Setelah selesai, bahan simak kembali dikelompokkan berdasarkan tingkat kesukaran ketika materi tersebut disimak oleh mahasiswa. Berdasarkan materi yang telah dikelompokan, peneliti membuat soal yang akan ditulis di lembar kerja mahasiswa. Adapun teks yang akan dikembangkan menjadi bahan sajar simak sebagai berikut : 
Tabel 2 : Pengembangan Teks Bahan Ajar Simak

\begin{tabular}{cllll}
\hline No. & \multicolumn{2}{c}{ Pengembangan Teks } & & Judul Teks Simak \\
& Simak Kearifan Lokal & & \\
\hline $\mathbf{1}$ & Kota dan Kabupaten & a) & Kota Cirebon \\
& Cirebon & b) & Tedhak Sinten Di Cirebon \\
& & c) & Panjang Jimat : Tradisi Maulid Nabi di \\
& & & Keraton Kesepuhan Cirebon \\
& & d) & Sega Jamblang \\
& & e) & Seni Buroq Cirebon \\
& & f) & Syawalan Gunung Jati \\
& & g) & Batu Bleneng \\
\hline $\mathbf{2}$ & Kabupaten Majalengka & a) & Durian Sinapeul Majalengka \\
& & b) & Kecap Majalengka yang Melegenda \\
& & c) & Kesenian Sampyong Khas Majalengka \\
\hline $\mathbf{3}$ & Kabupaten Indramayu & a) & Kesenian Tayuban \\
& & b) & Mimi Rasinah : Maestro Tari Topeng \\
& & & Cirebon \\
\hline 4 & Kabupaten Kuningan & a) & Cingcowong \\
& & b) & Kawin Cai \\
& & c) & Mengenal Seren Taun, Ritual Tahunan \\
& & d) & Saptonan Kesenian Khas Kabupaten \\
& & & Kuningan \\
& & &
\end{tabular}

2. Design : pada tahap ini, peneliti merancang bahan ajar simak berupa Lembar Kerja (LK) yang dilengkapi dengan bahan simak berupa audio. Majid (2005 : 173) bahwa bahan ajar merupakan informasi, alat, dan teks yang diperlukan guru/instruktur untuk perencanaan dan penelaahan implementasi pembelajaran. Merujuk pada pendapat tersebut, maka rancangan desain bahan ajar Lembar Kerja (LK) yang dikembangkan terdiri atas 4 aspek, yaitu; 1) Aspek materi; 2) Aspek penyajian Materi dan Latihan, 3) Aspek bahasa, dan 4) Aspek Grafika.

3. Develop : Tahap selanjutnya, mengembangkan racangan menjadi bahan ajar berupa Lembar Kerja (LK) yang dilengkapi dengan bahan simak. Hal ini merujuk pendapat Damayanti (2013) bahwapengembangan bahan ajar bentuk Lembar Kerja (LK), harus memenuhi berbagai persyaratan, yaitu persyaratan dikdatik, persyaratan konstruktif, dan persyaratan teknis. Maka, lembar kerja dikembangkan mempertimbangkan pada aspek materi, penyajian materi dan latihan, bahasa, serta grafika/gambar. Selanjutnya, bahan simak yang dikembangkan dari teks berorientasi pada kearifan lokal Ciayumajakuning dikonversi ke dalam bentuk audio.

4. Implement : Pada tahap ini, setelah bahan ajar jadi, bahan ajar diujicobakan secara terbatas pada mahasiswa untuk mengetahui kefektifan bahan ajar. Bahan ajar simak yang dilengkapi dengan lembar kerja (LK) diujicobakan kepada sepuluh orang mahasiswa yang mengontrak mata kuliah menyimak. Untuk mengetahui keberhasilan bahan ajar tersebut, mahasiswa memberikan respon dengan mengisi angket. Dalam angket tersebut, peneliti memberikan delapan pertanyaan di antaranya kesesuaian rekaman dengan lembar kerja, 
kejelasan rekaman, kesesuaian rekaman dengan soal dalam lembar kerja dan sebagainya. Berdasarkan angket yang diberikan kepada sepuluh mahasiswa diperoleh nilai rata-rata 90,93 dengan tingkat validitas sangat valid

5. Evaluate : Pada tahap ini, memvalidasi oleh teman sejawat untuk mengetahui kevalidan rancangan bahan ajar. Penilaian bahan ajar simak meliputi empat aspek yaitu aspek materi, aspek penyajian materi dan latihan, aspek bahasa, dan aspek grafika bahan ajar. Hasil validasi bahan ajar pada aspek materi bahan simak yang meliputi kesesuaian materi dengan kompetensi yang harus dicapai mahasiswa, kedalaman materi, tingkat keterbacaan, kesesuaian soal dan jumlah soal latihan mendapat nilai rata-rata 3. Sedangkan aspek penyajian materi dan latihan yang meliputi penyajian kompetensi dan tujuan perkuliahan yang harus dikuasai, materi yang disajikan mendukung kompetensi, urian materi mengikuti alur berpikir lingkup global, kejelasan rekaman, dan latihan disajikan mengikuti alur berpikir sederhana ke kompleks mendapat nilai rata-rata 3,5. Aspek bahasa dalam bahan ajar simak yang meliputi ketepatan penggunaan ejaan, ketepatan penyusunan struktur kalimat dalam penyajian materi dan pertanyaan latihan, dan bahasa yang digunakan sederhana dan komunikatif mendapat nilai rata-rata 3. Sedangkan, aspek grafika bahan ajar yang meliputi desain tampilan fisik bahan ajar dan penggunaan jenis dan ukuran huruf mendapat nilai rata-rata 3.

Setelah pengembangan dilaksanakan, bahan ajar digunakan dalam pembelajaran pada mata kuliah Menyimak pada semester gasal. Adapun hasil pelaksanaan dapat dilihat pada tabel berikut :

Tabel 2

Rekap Rata-rata Nilai Kemampuan Literasi Mahasiswa

\begin{tabular}{ccccc}
\hline No & Kegiatan & Bagian & $\begin{array}{c}\text { Lembar Kerja } \\
\text { Kegiatan }\end{array}$ & Rata-Rata Nilai \\
\hline 1 & Kegiatan 1 & Bagian 1 & LK.Keg. 1.1 & 3.63 \\
& & LK Keg. 1.2 & 3.7 \\
& \multirow{2}{*}{ Bagian 2 } & LK Keg. 1.3 & 2.6 \\
& & LK Keg. 1.4 & 2.8 \\
\hline 2 & Kegiatan 2 & Bagian 1 & LK Keg. 2.1 & 3.80 \\
& & LK Keg. 2.2 & 3.73 \\
& & Bagian 2 & LK. Keg. 2.3 & 2.60 \\
& & LK Keg. 2.4 & 2.80 \\
\hline 3 & Kegiatan 3 & Bagian 1 & LK Keg. 3.1 & 4.00 \\
& & & LK Keg. 3.2 & 4.13 \\
& & LK Keg. 3.3 & 3.07 \\
& & Bagian 2 & LK Keg. 3.4 & 3.23 \\
\hline 4 & & & LK Keg. 4.1 & 4.20 \\
& & & LK Keg. 4.2 & 4.37 \\
& & & LK Keg. 4.3 & 3.40 \\
& & & LK Keg. 4.4 & 3.57 \\
\hline
\end{tabular}

\section{Simpulan dan Saran}

Berdasarkan hasil dan pembahasan dapat ditarik kesimpulan bahwa bahan ajar simak berkearifan lokal untuk meningkatkan kemampuan literasi mahasiswa bahwa hasil Respon mahasiswa terhadap rancangan bahan ajar simak lembar kerja mahasiswa berkearifan lokal yang diujicobakan secara terbatas kepada 10 mahasiswa, menunjukkan hasil yang sangat

Tri Pujiatna, Elin Rosmaya, Nuning Wahyuningsih| Pengembangan Bahan Ajar Simak Berorientas Kearifan Lokal Untuk Meningkatkan Kemampuan Literasi Mahasiswa Pada Mata Kuliah Menyimak | 
valid dengan NPr (Nilai Presentase) 90,93\%. Selanjutnya, hasil validasi ahli dari dua orang dosen ahli menunjukkan hasil cukup valid dan dapat digunakan namun perlu direvisi kecil. Implementasi bahan ajar lembar kerja berkearifan lokal untuk mengingkatkan kemampuan literasi mahasiswa pada setiap kegiatan rata-rata nilai yang diperoleh rata-rata dari keempat kegiatan sebesar, yaitu, ; 3,18; 3,23; 3,6; dan 3,88.

Saran penulis bagi para peneliti yang ingin melakukan penelitian serupa yang perlu diperhatikan bahwa Sumber materi untuk bahan ajar simak bisa didapatkan dari informasi sekitar yang mengandung nilai-nilai kerafian lokal. Informasi yang memuat nilai kearfian lokal dapat diubah menjadi informasi tertulis dan dimanfaatkan sebagai bahan ajar.

\section{Daftar Pustaka}

Basyari.I.W. (2014) Nilai-nilai Kearifan Lokal (Local Wisdom) Tradisi Memitu Pada Masyarakat Cirebon (Studi Masyarakat Desa Setupatok Kecamatan Mundu). Jurnal Edunomic 2(1) 47-56. FKIP Universitas Swadaya Gunung Jati Cirebon ISSN 2337$671 X$.

Damayanti, D. S dkk. (2013). Pengembangan Lembar Kerja Siswa (LKS) dengan Pendekatan Inkuiri Terbimbing untuk Mengoptimalkan Kemampuan Berpikir Kritis Peserta Didik Pada Materi Listrik Dinamis SMA Negeri 3 Purworejo Kelas X Tahun Pelajaran 2012/2013. Jurnal Radiasi 1 (3) 58-62. Program Studi Pendidikan Fisika Universitas Muhammadiyah Purworejo.

Febriani, M. (2012). Pengembangan Bahan Ajar Apresiasi Dongeng Banyumas bagi Siswa SD Kelas Rendah. Jurnal Pendidikan dan Sastra Indonesia 1(1) 1-8. Universitas Negeri Semarang ISSN 2252-6722.

Hamdani. (2011). Strategi Belajar Mengajar. Bandung : Pustaka Setia.

Majid, Abdul. 2005. Perencanaan Pembelajaran Mengembangkan Standar Kompetensi Guru. Bandung :Remaja Rosdakarya

Maridi. (2015). Mengangkat Budaya dan Kearifan Lokal dalam Sistem Konservasi Tanah dan Air. Prosiding Seminar Nasional XII Pendidikan Biologi FKIP UNS 20-39.

Nurchaili. (2016). Menumbuhkan Budaya Literasi Melalui Buku Digital. Jurnal Libria 8(2) 197-209. Pascasarjana UIN Ar-Raniry ISSN 2086-1532.

Prastowo, A. (2011). Panduan Kreatif Membuat Bahan Ajar Inovatif. Yogyakarta: DIVA Press.

Republik Indonesia. (2003). Undang-Undang Sistem Pendidikan Nasional Bab I Pasal 1.

Republik Indonesia. (2005). Peraturan Pemerintah No. 19 tentang Pengembangan Materi Ajar. Widodo, C dan Jasmadi. (2008). Buku Panduan Menyusun Bahan Ajar. Jakarta : PT Elex Media Komputindo.

Wismanto, A. (2014). Pengembangan Bahan Ajar Pembelajaran Keterampilan Berbahasa Berbasis Sastra Untuk Siswa SD Kelas VI. Jurnal Tuturan 3(2) 586-593: FKIP PGRI Semarang ISSN 2089-2616. 